\title{
Original Galombang Dance Clothes: As Dance Elements in Reconstruction of Traditional Dance Clothing in Pariangan West Sumatra
}

\author{
Afifah Asriati ${ }^{1,{ }^{*}}$ Desfiarni $^{1}$ Irdhan Epria Darma Putra $^{1}$ \\ ${ }^{I}$ Dance \& Music Education Study Program, Universitas Negeri Padang, Padang, Indonesia \\ *Corresponding author.Email: afifahasriati@fbs.unp.ac.id
}

\begin{abstract}
This article aims to bring back the original clothing as elements of the Galombang dance in the reconstruction of the Pariangan village, Tanah Datar district, West Sumatra. The reconstruction was carried out because there were several elements of this dance equipment that had not been used for a long time, including the clothing according to what was in this dance. For this reason, its existence needs to be explored, namely how the form and use of the original clothes are really in accordance with what is in this dance. For this purpose, qualitative research approaches and types have been used with data collection techniques; interviews, observations and video recordings. Based on this method, it is found that the original materials and ways of using the clothes in this Galombang dance are characteristic of this dance outfit.
\end{abstract}

\section{Keywords: Clothing, Galombang Dance, Reconstruction}

\section{INTRODUCTION}

Galombang dance in Minangkabau can be grouped into types of ceremonial dance, because Galombang dance is only used as a means in ceremonies, namely traditional ceremonies. [1], [2]. Galombang dance is used in traditional events called alek nagari (village parties) such as for the batagak panggulu (crowning new pengulu) [1], besides that it is also used in wedding ceremonies [3], also used for silat teacher appointment ceremonies [4], [5]. And never used for entertainment or viewing.

Traditionally, dances in Minangkabau are danced by men in a martial arts style [6], [7], [8] and has never been danced by women. This is because the Minang cultural system does not recognize the appearance of women in dance. This means that women are not allowed to appear in public [9], [10]. Likewise with the Galombang dance. This article focuses on the clothing used in the Galombang dance in the Pariangan village. How is the material, how to wear the clothes, and the model (design). Galombang dance is danced by men, because of that the clothes used are of course men's clothes. The set of clothes commonly used in traditional Minangkabau dances are; a) loose clothes, b) galembong pants, d) deta (headband), d) sisampiang (side) ( [11], [12], e) there is also added with a belt.

At first glance, the clothes used in traditional dance in Minangkabau are almost the same. However, after a careful look, it turns out that it has different shapes, especially the headband and sisampiang. The difference lies in how to use it. How to use headbands depends on each village or there is a salingka nagari. For example in the Bayue village, Agam district, the design of the headband is called deta tanduak kuciang (cat horn headband), while in the village of Padang Magek, Tanah Datar district it is called deta pucuak rabuang (headband shoots shoots) [13]. Of course there are other forms of wearing headbands in other villages. Likewise with sisampiang, how to use it differently, some are sheathed to the body and some are tied to the waist in various forms as well.

In addition, in general, what has prevailed so far in Minangkabau, there is no special dress for one dance. One set of dance clothes can be used for any dance in each village. This means that there are no special clothes for certain dances. For this reason, it is necessary to identify this Galombang dance outfit carefully with sharp observation and in-depth interviews.

Based on the above phenomena, it is necessary to reconstruct the original dress of the Galombang dance in Pariangan village. Reconstruction is carried out based on past data to be brought back into the present. The data is the Galombang dance dress that is typical of the Pariangan village, especially the Guguak jorong. As far as the researchers got and also based on interviews with resource persons in the Pariangan nagari, the Galombang dance dress like the one in Pariangan does not exist anywhere else, especially the headband as an element of the Galombang dance dress. This research has become a concrete effort to preserve cultural objects that have not been used anymore.

In addition, Nagari Pariangan was designated as a tourist area by Budget Travel Magazine from New York 
America in 2012, which is to become one of the most beautiful villages in the world. Thus, of course the Pariangan village with this nickname by domestic and foreign tourists has become an attractive tourist destination. For foreign tourists, the unique and original culture in the places they visit is of particular interest to them. Therefore, it is necessary to reconstruct the original Galombang dance dress in the Pariangan village. If this Galombang dance dress turns out to be unique and unique, it can inspire tourists to come to this Pariangan village. Where this dance outfit is a complement that is an integral part of the overall dance element configuration.

Traditional Minangkabau dance must be in accordance with the philosophy and cultural values of the Minangkabau. In fact, this is one of the benefits of reconstructing the original Galombang dance dress, so that its authenticity can be found with elements that have been forgotten so far. By involving the authentic elements of what was once, but is not currently there or almost does not exist anymore [14] is absolutely necessary. Cultural objects in Minangkabau are always close to nature, because Minangkabau people make nature not just a place for them to be born, live, develop and die, but have a philosophical meaning. Nature is the philosophy of life of the Minangkabau people, which is revealed in the Alam Takambang Jadi Guru- Nature Developed Become Guru [1]. Likewise with traditional dance in Minangkabau. Therefore, clothing for traditional dances must be maintained. Because the part is inseparable from the philosophy of the Minangkabau people themselves. The clothing that must be maintained is the symbolic design and color [15].

\section{METHOD}

This type of research is qualitative. The subject is the dress of the Galombang dance in the Pariangan village. Data were collected through observation, interview, FGD, and documentation with video recordings. The validity of the data was obtained through triangulation of sources and triangulation of techniques. While the data analysis used the model of Miles and Haberman.

\section{RESULTS AND DISCUSSION}

As previously explained, the Galombang dance dress in Pariangan is different from the other Galombang dance clothes in Minangkabau. To find answers to problems and to achieve goals, it will be explained first 1) The history of the Galombang dance dress, 2) The reconstruction process of the Galombang dance clothes. Then also described different clothes from other Galombang dances regarding the material, process of use, and the final design of this headband and sisampiang.

\subsection{History of Galombang Dance Clothing before Reconstruction}

Based on the results of interviews with several informants in Pariangan, it is not known when this Galombang dance was created. What is clear is that they agree to say that since they knew that this Galombang dance has existed and is being used in this village.

In the Pariangan nagari, especially the Guguak jorong, this Galombang dance is used in the alek nagari (village / village party) event. The first meaning of Alek Nagari is mamancang alek di nagari (party in the nagari / village), namely the pacu jawi event, the second is mamancang alek mandirikan pangulu (the coronation party of new rulers). Only these two parties are activities of the Pariangan village community that use the Galombang dance. And now it is growing its use to welcome government guests.

Based on researcher's observations from August to September 2020, the clothes used by Galombang dancers are; 1) proprietary clothes (loose clothes), in black, red, yellow and other colors; 2) red and black galembong pants; 3) headband, made of saten cloth covered with sequins, wrapped around the head, the design is rencong ajik with a triangle design, red and black colors; 4) sisampiang, material of woven silungkang, with a rectangle $30 \mathrm{~cm}$ wide and $100 \mathrm{~cm}$ long, red and black in color, wrapped around the waist until it ends at the left side of the waist; and 5) belt, made of woven cloth with a length of $100 \mathrm{~cm}$ and a width of $10 \mathrm{~cm}$. For more details, see Figure 1 below.
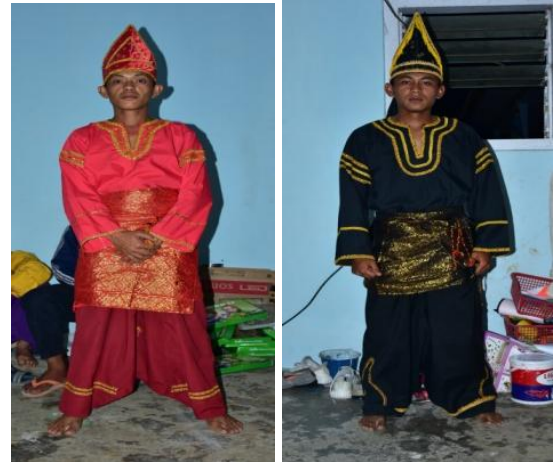

Figure 1: Clothing in use today

(Documentation: Afifah Asriati, 5 September 2020)

The clothes used for dancing are clothes that are also used for Randai performances [16], [17]. And clothing like this has long been used. So it seems that the clothes for dancing and for clever use the same clothes. Thus, the clothes of the Galombang dance in Pariangan village were identical to those of Randai.

\subsection{The Reconstruction Process of Galombang Dance Clothing}

The process of reconstructing the Galombang dance dress began by meeting the Galombang dance coach and asking whether the clothes he was wearing now were the original clothes of the Pariangan village. Apparently he said no. The originals are a) proprietary shirt, loose black shirt with a bay pot design but no pockets and a bag on the left and right sides, b) Galembong pants, black bottom pants design, c) batik headband with a special design, and d ) sisampiang made of Bugis sarong [16], [17]. Furthermore, the researchers asked the resource persons to 
reconstruct the original clothing according to the material, method of use, and the final design of the clothing elements that were different from the original clothes. The different clothing elements are the materials, how to use them, and the final design of the headband and sisampiang elements. While the elements of clothes and pants are different only in terms of color.

\subsection{Material, how to use, and design of the Destar}

Destar is one of the elements of the Galombang dance dress that has been discovered and has been used in the reconstruction of this Galombang dance. The materials, how to use, and the design of the Destar can be explained in the following research findings.

1) Material

The material used for this Destar is a blackish brown rectangular batik cloth. To provide a concrete picture of these materials can be seen in Figure 2 below.

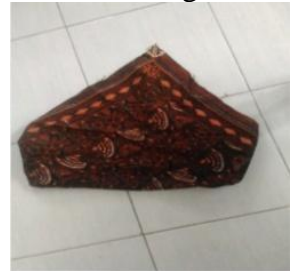

Figure 2: The headband material of a rectangular batik cloth (Documentation: Afifah Asriati, 5 September 2020)

2) The process and how to use Destar

The steps for how to use it are as follows; a) bringing together the opposite corners of the fabric so that they are triangular, b) parallel the folds are folded again to reduce the size of the triangle shape, two folds of each are approximately $10 \mathrm{~cm}, \mathrm{c}$ ) after that they are attached to the head starting from the back of the head, then the left end of the cloth is pulled to the right side over the right ear so that the end slopes downward. While the other end of the cloth is wrapped around the back of the head so that it can be inserted into the lower fold behind the head, and the end of the cloth appears behind the head. d) Then the top of the triangle is pulled back so that it looks like it is aligned with the bottom of the triangle. The following is a picture of the process and how to use

Destar.

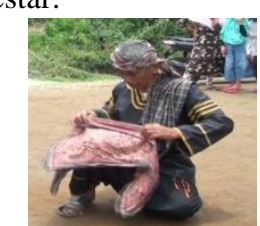

a)

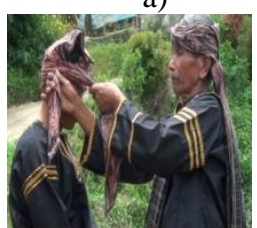

d)

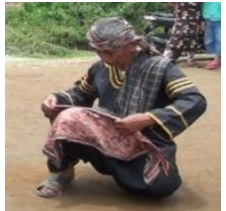

b)

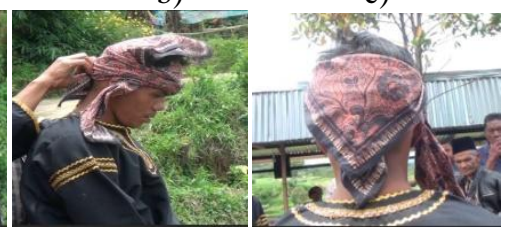

e)

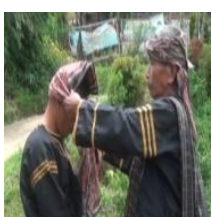

c)

f)
Figure 3: How to use a Destar in a Galombang dance outfit (Documentation: Afifah Asriati, 5 September 2020)
3) The final design of the Destar.

The final design of a headband like this is called a headband for young people [17]. The final design for using Destar can be seen in the following picture.

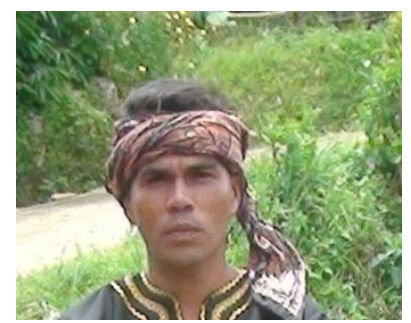

Figure 4: The final design of the Destar as a fashion element of the Galombang dance

(Documentation: Afifah Asriati, 5 September 2020)

\subsection{Materials, process how to use, and sisampiang design}

Materials, process methods of use, and sisampiang design in the findings of this study are:

1) Material.

The material used as a sisampiang is a Bugis sarong. For more details, see the following.

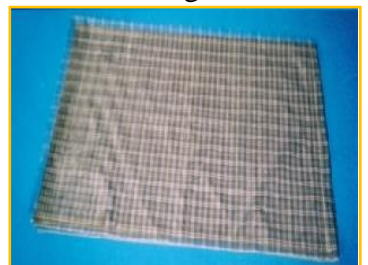

Figure 5: Bugis cloth as a sisampiang material from the Galombang dance clothing elements

(Documentation: Afifah Asriati, 5 September 2020)

2) The process and how to use sisampiang

The process for using sisampiang can be done in six stages, namely; a), the cloth is opened wide by holding the end of the sarong; b) the cover is folded in half; c), the sarong is folded again so that its width is approximately 30 $\mathrm{cm}$; d) the folded sarong is wrapped around the waist, starting from the back of the body carried to the front, ending at the left side of the body; e) then wrap the belt to tie the sides that have been attached earlier; f) Cover the belt with the top of the sheath so that only the end of the belt is visible. For more details, see Figure 6

3) The final design of the pole

The final design of sisampiang as an element of the Galombang dance outfit can be seen in the picture 7 . 

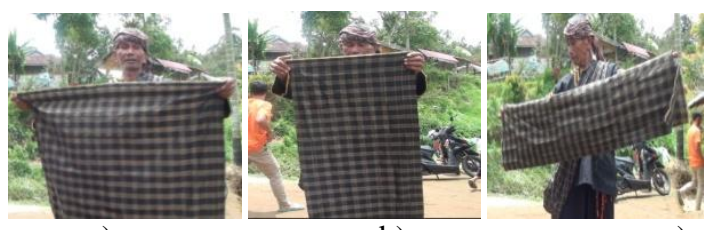

b)

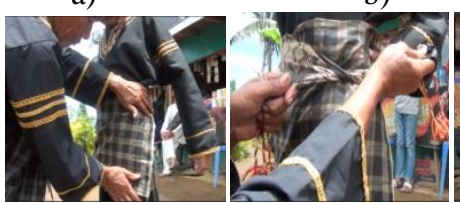

d)

e)

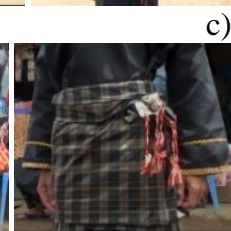

f)

Figure 6: The process of using sisampiang from Bugis cloth

(Documentation: Afifah Asriati, 5 September 2020)

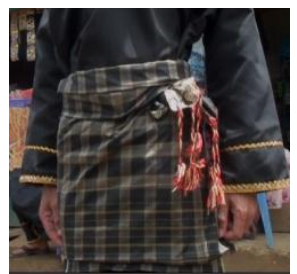

Figure 7 The final design of sisampiang as an element of the Galombang dance outfit

(Documentation: Afifah Asriati, 5 September 2020)

\subsection{The complete Galombang dance outfit}

As has been explained above that in addition to the headband and sisampiang which are material, how to use them, and the designs that have not been used for a long time, so are the colors of the clothes and pants. For that, then reconstructing the way to use the Galombang dance clothes with complete clothes according to the original clothes. The original complete outfit consists of 5 elements consisting of: 1) loose black shirt, 2) black galembong pants, 3) Destar made of batik cloth with a mudo child design, 4) sisampiang made of Bugis cloth with folds to the left, and 5) belt. The following can be seen a picture of the use of the original Galombang dance clothing with complete clothing.

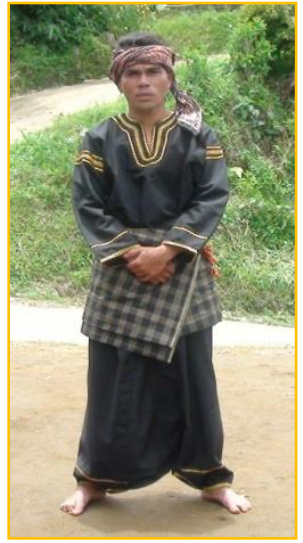

Figure 8: Complete outfit in Galombang dance (Documentation: Afifah Asriati, 5 September 2020)
The use of this black shirt and pants has been revealed Holt (1964) in his research that the figure of a male Minangkabau dancer with black trousers and loose shirt [10]. So is research [18] that the Sakin dance has always been performed by men in black clothes and pants.

With the reconstruction of the original Galombang dance clothing elements, it is in line with the statement [15] that what is important to be maintained in traditional clothing is the color and design. Because the original Galombang dance clothing has been found by carrying out this reconstruction, this finding is an effort to preserve cultural objects. Due to the efforts to maintain and preserve the arts in order to keep growing, one of them is by carrying out reconstruction activities. Nathania has also done this in her research, namely to restore the Persembahan dance clothes to their original form, because there have been many developments in the Persembahan dance clothes in various colors and designs [19].

\section{CONCLUSIONS AND SUGGESTIONS}

Based on the results of research on the Galombang dance dress which has been reflected by various credible sources in the jorong Guguak nagari Pariangan, it has been found that the original form of the Galombang dance dress has been found. In particular, two elements of clothing that have not been used for a long time are the headband with the headband design for the mudo and sisampiang children using a Bugis sarong that is folded to the left side, as well as loose shirts and black galembong pants. Thus, the reconstruction of these clothes is useful for maintaining the design and color of the original clothing that the Galombang dance had in Pariangan village.

It is hoped that the people of Jorong Guguak Nagari Pariangan can maintain the results of this reconstruction, and it is hoped that the village government will use this original outfit at the time of this Galombang performance if there are guests who come to Pariangan village especially to the Guguak jorong.

\section{ACKNOWLEDGMENT}

Thanks to Universitas Negeri Padang for Providing PNBP funding for research with this basic research scheme.

\section{REFERENCES}

[1] A. Navis, Alam Terkembang jadi Guru (Adat dan Kebudayaan Minangkabau), Jakarta: PT Grafiti, 1984.

[2] F. Yuliza, "Dari Tari Galombang ke Tari Pasambahan: Perubahan Tari Minangkabau dalam Perkembaangan Budaya Populerdan Industri Pariwisata," Jurnal Laga-Laga, Vol. 6, No. 1, Maret , pp. 80-90, 2020.

[3] K. Hidayati, Darmawati and H. Mansyur, "Peranan Silek Galombang dalam acara pesta Perkawinan di jorong Pandan Kenagarian Tanjung Sani kecamatan 
Tanjung Raya Kabupaten Agam," E-Jurnal Sendratasik. Vol. 7 No. 1. Seri F. September, pp. 915, 2018.

[4] N. Adnan, "Tari Galombang di Minangkabau menuju Industri Pariwisata," Journal of Urban Society's Art Volume 13 No. 2, Oktober, vol. 13 (2), no. http://repository.unp.ac.id/19163/, pp. 110-118, 2013.

[5] Adnan, Nerosti; Bujang, Rahmah; Edo, Juli, "The Galombang of Indonesia: A Cultural Dance Transition in Process," Jurnal Pengajian Melayu, Jilid 24, pp. 1-20, 2014.

[6] A. Asriati, A. Kosasih and Desfiarni, "Silat as the Source and Identity of the Minangkabau Ethnic Dance," Harmonia: Journal of Arts Research and Education 19 (2), vol. 19(2), no. DOI: http://dx.doi.org/10.15294/harmonia.v19i1.16106, pp. 71-83, 2019.

[7] N. "Nilai-Nilai Kearifan Lokal Melalui Tari Galombang Gaya Sasaran: Studi Sasaran Sebagai Sarana Pendidikan Kultural," Dance \& Theatre Review | volume 2 number 1, May 2019, vol. 2(1), no. DOI: https://doi.org/10.24821/dtr.v2i1, pp. 25-41, 2019.

[8] Sri, Rustiyanti; Djajasudarma, Fatimah; Caturwati, Endang; Meilinawati, Lina, "Estetika Tari Minang dalam Kesenian Randai Analisis TekstualKontekstual," Jurnal Seni dan Budaya Panggung. . No 1 Maret, vol. 23 (1) Maret, no. DOI: http://dx.doi.org/10.26742/panggung.v23i1, pp. 4256, 2013.

[9] A. Indrayuda, "Women domination in the Galombang dance: between the customary idealism and the market use," Harmonia: Journal of Arts Research and Education, vol. 17 (2), no. DOI: https://doi.org/10.15294/harmonia.v17i2, pp. 153$162,2017$.

[10] I. Utama, Tari Minangkabau: Dari Pancak dan Pamenan ke Tari Persembahan., Kuala Lumpur: University Malaya, 2017.

[11] M. Novitri, "Bentuk Penyajian Tari Piriang di daerah Guguak Pariangan," Ekpresi Seni, Vol 17. (1), vol. 17 (1), no. https://journal.isipadangpanjang.ac.id/index.php/Ekspresi/issue/view/5, pp. 115-128, 2015.

[12] Daryusti, "Falsafah Adat Minangkabau Sumatera Barat: Kajian Estetika Tari," MENARA Ilmu Vol. XII Jilid II No.80 Februari, pp. 143-151, 2018.

[13] Asriati, Afifah, "Minangkabau Dance Form in the Context of ABS-SBK Values)," in in Sixth International Conference on Languages and Arts (ICLA 2017), Padang, 2018.

[14] Djelantik, Seni Pertunjukan di Era Globalisasi., Yogyakarta: Gadjah Mada University Press, 1999.

[15] Soedarsono, "Pengantar Pengetahuan Komposisi Tari," in Pengetahuan Elemen Tari dan Beberapa Masalah Tari, Jakarta, Direktorat Kesenian Proyek
Pengembangaan Kesenian Jakarta Depatemen Peendidikan dan Kebudayaan, 1986, pp. 81-118.

[16] Baharudin, Interviewee, Wawancara. [Interview]. 29 Agustus 2020.

[17] Bunsu, Interviewee, Wawancara. [Interview]. 29 Agusstus 2020.

[18] L. Andriani, A. Asriati and H. Mansyur, "Struktur Tari Sakin di Nagari Pitalah Kecamatan Batipuh Kabupaten Tanah Datar," e-Jurnal Vol. 5 No. 1 Seri B September, pp. 1-10, 2016.

[19] I. Nathania, "Perkembangan Tata Busana Tari Persembahan di Kota Batam," Jurnal Seni Tari 9 (1), pp. 19-24, 2020.

[20] E. Sedyawati, Pertumbuhan Seni Pertunjukan, Jakarta: Sinar harapan, 1981.

[21] Soedarsono, Seni Pertunjukan Indonesia: Di Era Globalisasi, Edisi ketiga, Yogyakarta: Universisitas Gadjaah Mada Press, 2002.

[22] E. Sedyawati, Kebudayaan di Nusantara: Dari Keris, Tor-Tor sampai Industri Budaya, Depok: Komunitas Bambu, 2014.

[23] Nofitri, Miselia, " Bentuk Penyajian Tari Piriang di daerah Guguak Pariangan.," Ekspresi Seni, vol. 17 (1), no. https://journal.isipadangpanjang.ac.id/index.php/Ekspresi/issue/view/5, pp. 115-128, 2015. 